\section{DIGITAL COMMONS \\ @ UNIVERSITY OF SOUTH FLORIDA}

\section{ABO: Interactive Journal for Women in the Arts, 1640-1830}

\title{
Jane Austen's Anglicanism by Laura Mooneyham White
}

Andrew 0. Winckles

Wayne State University

Follow this and additional works at: https://digitalcommons.usf.edu/abo

Part of the Dramatic Literature, Criticism and Theory Commons, Educational Methods Commons, Feminist, Gender, and Sexuality Studies Commons, and the Literature in English, British Isles Commons

\section{Recommended Citation}

Winckles, Andrew O. (2013) "Jane Austen's Anglicanism by Laura Mooneyham White," ABO: Interactive Journal for Women in the Arts, 1640-1830: Vol.3: Iss.1, Article 12.

http://dx.doi.org/10.5038/2157-7129.3.1.12

Available at: https://digitalcommons.usf.edu/abo/vol3/iss1/12

This Reviews is brought to you for free and open access by Digital Commons @ University of South Florida. It has been accepted for inclusion in ABO: Interactive Journal for Women in the Arts, 1640-1830 by an authorized administrator of Digital Commons @ University of South Florida. For more information, please contact digitalcommons@usf.edu. 
Jane Austen's Anglicanism by Laura Mooneyham White

\section{Keywords}

Jane Austen, religion, Anglicanism, secularization, novels

Creative Commons License

(c) (i) $\odot$

This work is licensed under a Creative Commons Attribution-No Derivative Works 3.0 License. 
Laura Mooneyham White. Jane Austen's Anglicanism. Burlington, VT: Ashgate, 2011. \$89.95. 228 pp. ISBN: 978-1-4094-1863-4.

Reviewed by Andrew O. Winckles, Wayne State University

Given the sheer volume of Jane Austen scholarship it would hardly seem that there is any aspect of her life that remains unexplored in depth. Nevertheless the subject of her dedication (or lack thereof) to her faith remains a shockingly understudied subject. Critical opinions of Jane Austen's religion range from the dismissive (arguing that religion plays little role in Austen's novels) to the cynical (arguing that the author actively subverts established religion in her published work). In Jane Austen's Anglicanism, Laura Mooneyham White aims to correct this imbalance by arguing that the best way to understand Austen's faith and the deep impact it had on her work is by first understanding the otherness of eighteenth-century religious practice within the Church of England. As White argues, "To read Austen is to read a missive from a different world - one familiar but strange" (127), and nowhere is this familiar strangeness more evident than in how Austen treats religion. Thus, a more thorough understanding of how Austen would have perceived the role of the Church in her life opens up more nuanced readings of the novels - readings that have largely escaped a mostly secular modern readership but which would have been readily apparent to the original audience.

The Church of England changed very little between 1660 and 1830, in large part as a reaction to the religious enthusiasm of the Civil War, an enthusiasm that was always simmering beneath the surface of eighteenth-century culture. As a result eighteenth-century Anglicanism has largely been treated as an unimportant backwater - a world of absenteeism among the laity, pluralism among the clergy, and latitudinarianism among the episcopacy. Religious observance during this period is thought to have been lax at best (though W.M. Jacob argues that lay piety remained high during the period) and thus to have exercised little influence on the population. Though excellent studies by Jon Mee, Saree Makdisi, David Hempton, Leigh Eric Schmidt, and D. Bruce Hindmarsh ${ }^{1}$ have reminded us of the distinct otherness of eighteenth-century religious practice in the dissenting and evangelical traditions, we have largely forgotten the different kind of otherness that characterized established practice. This type of belief centered not on extraordinary spiritual experiences and visions but the ritual observance of established practices that worked to confirm a vision of society predicated on order and natural design.

Born to an ordained Church of England priest, Jane Austen would have been thoroughly inculcated in the forms of Anglican spirituality from a young age. Her native county of Hampshire was one of the most devoutly Anglican in the country and many of her friends and family, including her brothers, pursued a career within the established Church. Austen would have likely attended church two times on any given Sunday, in addition to the daily morning and evening prayers prescribed by the Book of Common Prayer. According to White's conservative estimate, Austen would have said the Lord's Prayer in excess of 30,000 times over the course of her life. She would also have subscribed to an eighteenth-century theology which argued that the world was a highly ordered place - designed by God and structured according to the Great Chain of Being - and everyone had his or her designated place and was expected to fulfill a particular role. Thus poverty was not seen as something that could, or should, be corrected. Instead the 
parish system was designed to provide aid and charity to the poor. If all of this seems relatively unimportant, especially as relates to Austen's artistic production, this is because we have largely forgotten the vital role religion would have played in her life. If her religious practice seems somehow ordinary, that is because it was; and if religion does not seem to play a crucial role in her novels, that is because we have forgotten how to look for it.

White's book, then, seeks first to recapture Austen's religious inheritance and then trace how it plays out in her work. Thus the book is divided into two parts, with the first three chapters laying out a detailed picture of Anglican belief and practice during the eighteenth century (largely as presented above) and then arguing for the orthodoxy of Austen's adherence to this system. The first section of the book is immensely useful even to scholars who are not otherwise interested in Austen, as it provides one of the clearest and most concise expositions of eighteenth-century practice within the Church of England to date. By moving through the history of the Georgian Church and laying out the key theological ideas that informed its (and Austen's) worldview, White makes a clear and convincing argument for the fundamental otherness of the Church prior to 1830. Far from being a part of some secular progression away from devout practice, the Church of Austen's day, while slowly changing, was still very much a part of the fabric of British society.

Key to White's argument for Austen's orthodoxy, which she pursues at length in the second section of the book, is: first, a refutation of the idea that the signature wit (and sometimes malice) that is displayed in the novels and letters stamps Austen as someone uninterested in religion and; second, a focus on the argument from design as a key component that structures her novels. Thus, in Chapter Four, "Wordplay, Candor, and Malice," White pursues the first of these topics, arguing that " ... the moral problem of wit dominates Austen's fiction," and that " $[\mathrm{t}] \mathrm{he}$ propensity of wit to become morally unmoored, to move beyond the 'descrying' of 'foibles' into the pleasures of malice and self-righteousness, was an ever-present danger for Austen, and her awareness of this fault was keen" (132). Indeed one of the primary reasons Austen's fiction has remained popular is her trademark wit, and it is this propensity for clever and sometimes malicious wordplay that has prompted some critics to mark her as a largely irreligious writer. However, as White makes clear, Austen was well aware of her tendency to take wit too far into malice (a characteristic that is most on display in her letters to her sister Cassandra) and sought to discipline it in her life and work. The three extant prayers that she wrote for family use return time and again to the "sins of the tongue," while one of the chief lessons characters like Elizabeth Bennet and Emma Woodhouse learn is how to properly discipline wit-using it only to correct what they see as immoral or absurd, and not as a weapon with which to harm others. Wit, for Austen, both personally and artistically, could be turned to both moral and immoral uses, and it is the disciplining of wit that she posits as one of the crucial religious questions in her work.

In Chapter Five, White addresses another of the key religious concerns of Austen's novels-the problem of fiction or "world making" in a religious context. This was, of course, a vexed issue for religious writers from Richardson to Hannah More, with many evangelicals condemning novels and novel reading due to their realistic content that could potentially lead young women astray. Austen was well aware of the problems of an insufficiently disciplined imagination and sought to defend novels by using her authority as author to provide them with a moral structure - using the eighteenth-century argument from design to control her plots and bring 
them to their natural and proper ends. ${ }^{2}$ Thus, perhaps the most important character in all of her novels is "Jane Austen," the god-like narrator who structures everything according to its natural design. As White argues, "Judgment and religious principles led Austen's fiction to endorse doing what was right, even when doing so was difficult; the same forces also shaped each novel to reward the exercise of virtue" (184). This, for Austen, was the proper use of the imagination as informed by natural law and God's structure of society. This was primarily a religious objective and one that she executed so successfully that generations of readers - many of whom are secular and do not hold the same values - nevertheless find themselves endorsing those values within the imaginative space of novel.

In tracing these themes in detail, White thus goes a long way towards restoring the lost religious context of Austen's life and work. Much work remains to be done on eighteenth-century religion and literature, and especially on Anglicanism and literature as, despite its monolithic cultural status, we still seem to know (or care) relatively little about how Establishment practices worked themselves out in the rapidly shifting cultural landscape of the eighteenth century. Instead of viewing the eighteenth-century Church as a relatively stagnant institution that participated in some sort of un-halting march towards modern secularism, it is perhaps more useful to regain an understanding of the particularities of Anglican belief and practice. That we tend to read secularism back onto Jane Austen thus says more about us and our critical investments than it does about her. In this, White's main achievement in Jane Austen's Anglicanism is to remind us that eighteenth-century belief was far more differentiated and vibrant than we tend to believe and that, viewed through this lens, Jane Austen's belief becomes a crucial component of her life and work. 


\section{Notes}

1. See Jon Mee, Dangerous Enthusiasm and Romanticism, Enthusiasm, and Regulation; Saree Makdisi, William Blake and the Impossible History of the 1790's; David Hempton, Methodism: Empire of the Spirit; Leigh Eric Schmidt, Hearing Things; and D. Bruce Hindmarsh, The Evangelical Conversion Narrative. For more on eighteenth century religious practice within the Church of England, see W.M. Jacob, Lay People and Religion in the Early Eighteenth Century, and E.G. Rupp, Religion in England, 1688-1791.

2. For a more detailed treatment of the argument from design and Austen's novels see Colin Jager, The Book of God: Secularization and Design in the Romantic Era. Philadelphia: U of Pennsylvania P, 2006. Print. 